\title{
Law and regulation of retained organs: the ethical issues
}

\author{
John Harris
}

School of Law, University of Manchester

Organ retention has been with us for millennia. Walk into virtually any cathedral and many a church in Europe and you will find an array of retained organs or tissue, allegedly originally the property of assorted saints, or even of God, and almost certainly collected without proper informed consent and retained in less than secure conditions. In our own time the complexities of organ collection, retention and use have proliferated.' The events at Alder Hey Children's Hospital and the debates about the ethics of biobanking all over the world have dramatically highlighted the complexity, the difficulty and the moral importance of these issues. ${ }^{2}$ Some of these issues have to do with the question of who can give permission for or consent to such removal and retention. Other issues involve consideration of whose rights or interests are engaged when cadaver organs and tissue are removed and retained, just what in particular is the nature, extent and force of those rights or interests, and how they are to be balanced against other moral considerations. These questions are the subject of this paper. We will not, however, here be concerned with the issues of genetic privacy, the security of genetic information.

There is no doubt that, as the 'Redfern Report' on issues concerning retention of tissue and organs at Alder Hey Hospital in Liverpool emphasises: '[T]issue and organs which have been archived are an invaluable asset for medical research. ${ }^{3}$ The retention of tissue and organs is also sometimes required both by law and ethics for other reasons connected with the public good and hence the good of individuals, for example, to explain death so that, where possible, measures can be taken to prevent further avoidable death or suffering. Where such powerful moral reasons are present, there is good reason to retain tissue and organs following death and good reasons for anyone whose consent is required before such removal and retention can take

* I am indebted to my colleagues Neil Duxbury, Charles Erin and Søren Holm for their incisive comments on an earlier draft of this paper.

1. Although collection, retention and use can raise separate issues, I will use the term 'organ retention' to cover all three processes unless otherwise indicated.

2. For some of this debate, see D Korn MD Contribution of the human tissue archive to the advancement of medical knowledge and public health Report to the National Bioethics Advisory Commission (1998) and Health Science Information Banks - Biobanks Report the Danish Council of Ethics, Copenhagen (1996). See Protocol for the UK Biobank sponsored by The Welcome Trust, Medical Research Council and the Department of Health (2002).

3. The Royal Liverpool Children's Inquiry Report (the Redfern Report) (London: The Stationary Office, 2001) p 445. See also the Report of the Public Inquiry into children's heart surgery at the Bristol Royal Infirmary 1984-95 Learning from Bristol (Cm 5207(1), 2001). 
place to give that consent. Absent the good moral reasons for organ and tissue examination and retention, either because nothing useful can be learnt from them, or because they have been retained in a way which prevents such beneficial use, there is no justification for either taking or retaining tissue and organs.

The main trend in biomedical ethics in recent years has been patient-centred. This has meant, in effect, a retreat from medical paternalism, but equally a retreat from the paternalism of parents and other relatives in favour of maximising the self-determination of patients. ${ }^{4}$ The relevant consents in medicine are always first and foremost those of a competent subject and, for example, the consent of parents, relatives or friends is only in play (a) absent such competent consent and (b) where consent of relatives represents a reasonable interpretation of the patient's best interests. This makes the question of parental consent for organ removal and retention particularly problematic because of the relationship of such consents to the question of the best interests of the children. To these and other related ethical issues we must now turn.

\section{INTRODUCTION}

If morality is 'the science of the good', ethics is the study of that science, although in common usage 'ethics' and 'morality' are usually interchangeable terms. A matter has ethical importance whenever harm or benefit to persons is at issue. The individuals' concern about matters of ethical importance, however, may be personal or impersonal. We all have an important impersonal interest in morality. That is to say, it matters to us that good is promoted and that evil frustrated, hence our ethical interest is engaged whenever something that matters morally is in contemplation. However, while we have this very comprehensive impersonal interest in morality or in ethics, we may only complain that we ourselves have been treated unethically where our legitimate moral rights or interests have been affected by the conduct of which we complain. There are then two very general approaches to the ethics of organ retention. One is to decide whether what has been done is ethical and the other is to determine who (if anyone) has been wronged ethically by what has been done. Who has a legitimate moral complaint? Of course, where people have legitimate moral complaints it must be true that something unethical has occurred, and here we will largely be concerned with the question of who may have been wronged.

There are a number of legitimate rights or interests that are in play in the context of organ retention. Let us start with the issue of consent, because this has been a central issue on the controversy surrounding organ retention.

\section{CONSENT}

I will start by saying something about consent and its role in medical contexts generally, and in posthumous organ retention in particular. I will then explore the issue of the particular consents that might be required.

4. See, for example, Gillick $v$ West Norfolk and Wisbech Area Health Authority [1985]

3 All ER 402; and $F v$ West Berkshire Health Authority [1989] 2 All ER 545. 


\section{Consent generally ${ }^{5}$}

The centrality of consent in health care is a function of the importance accorded to autonomy; and autonomy itself is part of our concept of the person because it is autonomy that enables the individual to 'make her life her own'. Choices are self-defining, but also they are self-creating. ${ }^{6}$

However, while the importance of consent derives from our concept of the person, its procedural primacy in health care in the UK, the US and some other jurisdictions is owed to the common law tradition, which protects individuals from assaults - unlawful touchings. It is consent which makes laying your hands on someone else lawful - hence the importance of obtaining valid consents to all medical procedures which involve interventions which compromise the bodily integrity of patients.

Treating someone who has not consented and who is capable of choosing for him or herself whether or not he or she wants treatment is a denial of the ethic of respect for persons. This principle of respect for persons is a cornerstone of medical ethics, and is endorsed by the law in most jurisdictions. Both ethics and prudence therefore combine to support it, so let us begin by considering it further.

\section{Respect for persons}

Respect for persons is widely regarded as the fundamental basis of any ethics involving human beings. It is an assumption of our society and indeed most, if not all, others that it is persons that have the highest moral importance or value. There may be differences over how to define a person and difficulties about when persons begin and cease to exist, but the ultimate value of those deemed to be persons is largely unchallenged. The philosophical literature shows that this assumption can be explained and defended in a number of ways. Here, we need only note and endorse the wide acceptance of this principle by most religions and cultures. The term 'respect for persons' encapsulates this 'ultimate' moral importance and attempts to give it content - to explain just what those who accept the moral importance of persons are committed to in concrete terms. Respect for persons understood as a moral principle sets out the ways in which it is appropriate to behave towards those who matter morally.

Respect for persons, then, not only describes the outcome - treating others in morally appropriate ways, but also points to the origin of this obligation in the ultimate or supreme moral value of individuals of a particular sort.

5. In this section I have drawn on my papers 'Consent and end of life decisions' in (2002) J Med Ethics (forthcoming) and 'The concept of the Person and the value of life' (1999) 9(4) Kennedy Institute of Ethics J 293.

6. This paper draws on my thoughts first published in a number of places, including: 'Life and Death' in E Craig (ed) the new Routledge Encyclopaedia of Philosophy (London: Routledge, 1998); and in my 'Euthanasia and the Value of Life' and other essays by myself and John Finnis on euthanasia in J Keown (ed) Euthanasia Examined: Ethical Clinical and Legal Perspectives (Cambridge: Cambridge University Press, 1995) pp 6-71. The concept of autonomy used and defended here differs markedly from that often associated with Kantian philosophy. For an excellent elaboration and defence of a Kantian conception of autonomy, see O O'Neill Autonomy and Trust in Bioethics (Cambridge: Cambridge University Press, 2002). 
Respect for persons requires us to acknowledge the dignity and value of other persons and to treat them as ends in themselves and not merely instrumentally, as means to ends or objectives chosen by others. Respect for persons has two distinct dimensions:

1. respect for autonomy; and

2. concern for welfare.

When I suggest that these elements are crucial to any conception of respect for persons, I mean simply that no one could claim to respect persons if their attitude to others failed to take account of, and indeed exhibit, these elements. Autonomy, the value expressed as the ability to choose and have the freedom to choose between competing conceptions of how to live, and indeed of why we do so, is connected to individuality in that it is only by the exercise of autonomy that our lives become in any real sense our own. By shaping our lives for ourselves we assert our own values and our individuality. Our own choices, decisions and preferences help to make us what we are, for each helps us to confirm and modify our own character and enables us to develop and to understand ourselves. So autonomy, as the ability and the freedom to make the choices that shape our lives, is quite crucial in giving to each life its own special and peculiar value. It is because we accept that the meaning, purpose and indeed the distinctive uniqueness of an individual's life is given largely by acts of self-definition and self-creation that we are concerned to protect those attempts at self-creation, even where we are convinced that they are misguided or even self-harming.

Concern for welfare compliments autonomy in that it provides the conditions in which autonomy can flourish and our lives be given their own unique meaning. Concern for welfare ceases to be legitimate at the point at which, so far from being productive of autonomy, so far from enabling the individual to create his or her own life, it operates to frustrate the individual's own attempts to create their own. Welfare thus conceived has a point, as does concern for the welfare of others; it is not simply a good in itself. We need welfare, broadly conceived in terms of health, freedom from pain, mobility, shelter, nourishment and so on, because these things create the conditions which not only maximise autonomy, but also give autonomy minimum scope for operation. In this way, welfare is liberating; it is what we need to be able to pursue our lives not only to best advantage, but also in our own way.

Informed consent is a dimension of respect for persons in that it is through consenting to things that affect us that we make those things consistent with our own values. When we consent to what others propose, we make their ends and objectives part of our own plans; so, far from being merely the instruments of others, we incorporate their plans and objectives into our own scheme of things and make them in that sense our own. That is why respect for persons precludes the non-consensual use of others merely for our own benefit and explains why their consent to what we propose transforms them from mere tools of ours into self-regulating autonomous beings whose chosen path we facilitate.

Such respect must then apply both to acts and omissions, to doing and refraining. If we respect the life plans and choices of others, it will matter to us that those plans and choices are not frustrated. It should make no difference to us (and certainly does not to them) that the frustration results from omissions rather than actions. 


\section{The role of consent in posthumous organ retention}

In its consultation document issued in February 2002, The Retained Organs Commission expressly adopted a set of 'clear ethical principles' first proposed by the UK Chief Medical Officer. ${ }^{7}$ These ethical principles, initially only intended to cover so called voluntary post-mortems, include the following:

- Informed consent: ensuring that permission is sought and given on the basis that a person is exercising fully informed choice; consent is a process not a one off event.

- Time and space: recognising that a family member may need time to consider whether to agree to a post-mortem examination and to consider donation of tissue and organs and will not wish to feel under pressure to agree in the moments after death. ${ }^{8}$

Later, the Consultation Document proposes the adoption of the following principles, which it describes as 'ethical values':

(a) respect for the wishes of the deceased person, if these are known;

(b) respect for the feelings and wishes of bereaved relatives and friends, with a means of resolving disagreements between them;

(c) full information to, and communication with, affected persons, leading to informed consent to retention and/or use; ...

(g) ensuring that any retained organs and tissue are put to legitimate and ethical uses in line with any wishes expressed by the deceased person and his or her family. ${ }^{9}$

The role of consent in posthumous organ retention is highly problematic. Neither the Retained Organs Commission nor the Chief Medical Officer before them offer any arguments as to why these consents are ethically required, or even relevant. Perhaps they are assuming that, as in other areas of medicine, consent is required by acceptance of the principle of autonomy or by the principle of 'respect for persons'; however, as we shall now see, this cannot be the case. For, even where the deceased has made a competent direction prior to their death as to the disposal of their tissue and organs posthumously, such a 'consent' is not like the other paradigm cases of consents in medical contexts why?

First, although both ethics and law recognise that persons may have enduring interests that survive death (more of which below), posthumous interests are not necessarily like those interests that consent standardly protects. We have seen that the principal function of consent is either to protect and, indeed, facilitate autonomy, or to protect bodily integrity from acts that, without consent, constitute a violation. Autonomy involves the capacity to make choices, it involves acts of the will, and the dead have no capacities - they have no will, no preferences, wants nor desires, the dead cannot be autonomous and so cannot have their autonomy violated. Equally, the dead cannot have their bodily integrity violated,

7. Retained Organs Commission 'A Consultation Document' (London: Department of Health, 2002).

8. Retained Organs Commission, $n 7$ above, $p 7$, para 16.

9. Retained Organs Commission, $n 7$ above, p 28, para 64 . 
for violation consists not simply in a breach of bodily integrity, but in a breach of bodily integrity that is not consented to. Necrophilia may be unethical; it may even be a crime, although it is not altogether straightforward to identify what crime it might be. ${ }^{10}$ If it is treated as a crime, it is so because it is alleged to raise issues of public decency. Some offences that have been recognised (usually, one cannot help thinking, more in the spirit of a desperate attempt to find something illegal about it) include 'mutilating a corpse' and 'showing indignities to the dead", " but whatever offence it involves, it is not the crime of rape, it is not a crime that involves violation.

Are there posthumous rights?

'Offences' against the dead do not involve violations of their autonomy; ${ }^{12}$ indeed, as been established in English law at least, the human body neither owns itself (contra many theories of self-ownership concerning the bodies of the living $)^{13}$ nor is it usually owned by others, unless those others have 'mixed their labour' with the corpse or parts of it, thereby enhancing its value or utility. Interestingly, in $R v$ Kelly $^{14}$ Rose LJ in the English Court of Appeal, discussing the ownership of dead bodies noted:

'Furthermore, the common law does not stand still. It may be that if, on some future occasion, the question arises, the courts will hold that human body parts are capable of being property for the purposes of s.4 [of the Theft Act 1968], even without the acquisition of different attributes, if they have a use or significance beyond their mere existence. This may be so if, for example, they are intended for use in an organ transplant operation, for the extraction of DNA or, for that matter, as an exhibit in a trial.'

While Rose $\mathrm{LJ}$ does not say that such purposes would override any particular contrary claims, it is surely not insignificant that altruistic or public interest purposes are identified as the sorts of things that may, of themselves so to speak, give rise to entitlements of ownership and hence to powerful interests that may defeat other sorts of claims to possession of bodies or body parts. Anticipating the discussion to come, it is difficult to believe that many of the purposes which make the use of retained tissue and organs morally appealing, including maintenance of the human tissue archive, would not be just the sorts of considerations that would (or ought to) put a rocket under the common law of

10. For an account of the ways in which the law has attempted to deal with necrophilia, see D S Cook and D S James 'Necrophilia: case report and consideration of legal aspects' in (2002) 5 Med L Int 199.

11. Cook and James, n 10 above..

12. There is some legal support for this: see People v Kelly and People v Sellars California Supreme Court cited in Cook and James, n 10 above at p 202.

13. A locus classicus is G A Cohen Self-Ownership, Freedom, And Equality (Cambridge: Cambridge University Press, 1995) p 68 (this originally appeared in Cohen's 'Self-ownership, world-ownership, and equality' in F Lucash (ed) Justice And Equality Here And Now (Ithaca, NY: Cornell University Press, 1986) p109). See also H Steiner An Essay on Rights (Oxford: Blackwell, 1994).

14. See $R v$ Kelly [1998] 3 All ER 741, CA. Ownership of bodies or body parts which results from 'the exercise of work or skill' is, however, subject interestingly also to the entitlement to possession for the purposes of burial. 
the sort to which Rose LJ alludes. Moreover, Andrew Grubb ${ }^{15}$ has suggested that the Kelly case, and indeed Doodeward, on which the Court of Appeal partly relied in Kelly, "may be better explained as cases of "first possession" conferring property rights. The analogy would, in law, be with wild animals that are killed or wild flowers that are cut, the "first possessor" acquires the rights over them where previously there had been none'. The significant observation here is 'where previously there had been none'. This shows that (possibly?) excepting obligations to possess a body or body parts for the purposes of burial the family have no remaining rights at law to the body or its parts which can compete against altruistic or public interest uses. What the moral basis of any rights to possession of the body or its parts possessed by the next of kin may be is not articulated. So, for example, if the law is satisfied that the bodies may be buried without certain bits and pieces, it is not clear that there is any remaining entitlement to possession for the purposes of burial vesting in the relatives. Suppose, as may well be, that the entitlement to possess the body for the purposes of burial is historically, and therefore probably, also at common law solely, or even principally, for the purposes of securing public health and public decency, and possibly also to ensure that the cost of securing these things does not fall on charitable institutions, or the community or the state, but rather on the family. There is then a real question as to whether there is any remaining moral base, once the public health and public decency concerns about bodies not being left rotting or exposed in public places have been subtracted, that can compete with the altruistic and public interest concerns addressed, for example, in Kelly.

Suppose that you and I are expert swimmers lounging in our deck chairs on the beach. A child gets into difficulties in the bay. Arguably, both us have a strong moral obligation to effect a rescue (although under English law - shame on us that we are so wicked - we have no such legal obligation; contra France, for example), then, if I effect the rescue, it is unclear that you have an entitlement to wrestle with me for the right to bring the child safely to shore. Your obligation is satisfied if another discharges it - it is not an exclusive right, merely a residual obligation - if no one else does it, then you must.

Now, to this it might be responded as follows: ${ }^{16}$ suppose the facts are the same but the child drowning is my daughter, then arguably the same is true; but if you take her to hospital and start to withhold consent for particular therapies, I might rightly claim that my prerogative with respect to my child has unjustifiably been usurped. Here it is a (quasi) exclusive right and not a residual entitlement. But notice that if we sympathise with my claim to priority here, it is principally because any rational person, and even a less than rational society, would trust me rather than you to have the best interests of my child at heart, at least in the absence of strong evidence to the contrary. So that my claims against you to determine what happens is parasitic upon considerations of the child's best interests. Absent those considerations - because the child has died in the ambulance - and my obligation and entitlement is rather different. If I claim priority here, it is because I have a greater claim to sympathetic consideration, not a greater obligation or right to dispose of the body.

15. Catherine Yates drew my attention to Andrew Grubb's comments in I Kennedy and A Grubb Medical Law (London: Butterworths, 2000) pp 2246-2247.

16. I am indebted to Margot Brazier for this point. 


\section{Posthumous rights}

What about the rights of the dead? It is doubtful as to whether there is any such thing as a posthumous right. There are two main theories of rights: choice theory and interest theory. Choice theory sees rights as securing 'the protection and promotion of autonomy or liberty' and interest theory sees rights as serving to further individual well being or welfare ${ }^{17}$ Clearly, on choice theory there are no such things as posthumous rights, because the dead are not autonomous and so their rights cannot be analysed in terms of choices. Even according to interest theory, posthumous rights are doubtful because, arguably, the dead have no welfare interests left to be served, and such interests as they might be said to retain have to be strong enough to impose a duty on others. Joseph Raz, for example, suggests that an individual is capable of possessing rights 'if and only if ... his well-being is of ultimate importance'. Now, the dead have no wellbeing for the simple and sufficient reason that they have no 'being' at all; they are not beings, but ex-beings or former beings. They were once beings whose well-being had ultimate value, but no more! $!^{18}$

Shakespeare gave eloquent expression to both sides of the coin. Mark Anthony, in Julius Caesar, certainly talks as if the dead can be wronged: 'I rather choose / to wrong the dead, to wrong myself and you / Than I will wrong such honourable men. ${ }^{19}$ But in Macbeth, Shakespeare takes a harder line - Macbeth himself, talking of the murder of Duncan whom he has 'sent to peace' says: 'Duncan is in his grave; /After life's fitful fever he sleeps well; / not steel, nor poison, / Malice domestic, foreign levy, nothing / Can touch him further. ${ }^{20}$ However, although the dead, on Anthony's view, can be wronged, on the normal distinction between harming and wronging they probably cannot be harmed. Harming involves damage to the body or the mind, whereas 'wronging' involves the violation of rights or of morally protected interests. $^{2 t}$

\section{Persisting or 'critical' interests}

There is a real sense in which individuals may have some interests that survive their death, and hence there are some senses in which an individual's interests are still in play post mortem. For example, if I have an interest during my life that my children are provided for after my death and I seek to secure that interest by executing a will, it remains true that if the provisions of that will are not respected, my interests have been harmed, although, of course, neither will I be aware of that fact, nor will it affect my well-being in any way. ${ }^{22}$ Interestingly for

17. On rights theories generally, see L W Sumner The Moral Foundation Of Rights (Oxford: Clarendon Press, 1987); J Waldron The Right to Private Property (Oxford: Clarendon Press, 1988) ch 3; Steiner, n 13 above; R Dworkin Taking Rights Seriously (London: Duckworth, 1977) and Life's Dominion (London: Harper Collins, 1993) pp 210-216.

18. See J Raz The Morality of Freedom (Oxford: Clarendon Press, 1986) p 166. A related conception in terms of welfare rather than well-being is offered by Sumner, $n 17$ above, $p 47$.

19. W Shakespeare Julius Caesar Act III, Scene II.

20. W Shakespeare Macbeth Act III, Scene II.

21. On this distinction, see J Feinberg Harm to Other (New York: Oxford University Press, 1984) p 102; and see J Harris Wonderwoman and Superman (Oxford: Oxford University Press, 1992) p 84ff.

22. See, for example, Dworkin (1993), n 17 above, pp 210-216; and Harris, n 21 above, p $100 \mathrm{ff}$. 
our present argument, at English common law we cannot determine by will what will happen to our bodies after death, but an exception to this common law rule was introduced by The Human Tissue Act $1961,{ }^{23}$ which makes an exception in the case of disposition for therapeutic purposes. If anything can be read into this exception, it is perhaps the idea that therapeutic dispositions have a moral, and perhaps social, priority that overrides other considerations. ${ }^{24}$

While such interests deserve some respect, they are, I would submit, relatively weak $^{25}$ when compared with the interests of living persons who exist to be harmed in person by the neglect of those interests. The issue of whether or not persisting interests of the dead should be respected is not different in principle from the question of whether their wishes as to the disposal of other parts of their estate should be respected. The appropriate principle should be that their wishes when alive as to post mortem affairs should be respected subject to reasonable demands of public interest. This is not because we respect the autonomy of the dead, but because living people want a mechanism for disposing of their assets after death and recognise that if their wishes are to be carried out, reciprocity is required. They must implement the now-extinguished wishes of the dead in order to have confidence that their own wishes will be implemented once they are no longer capable of wishing anything. This is, of course, the case with wills and other testamentary dispositions (the public interest is, after all, respected in the payment of death duties - taxes which are usually very much against the wishes and interests of the dead). ${ }^{26}$ We should remember that the public interest serves principally the interests of existing and future individuals. Research and therapeutic use of archived samples of deceased citizens might be regarded as analogous to taxing their estate to raise revenue. ${ }^{27}$ The point is, of course, that the requirement to respect such interests is much weaker than the obligation to respect rights of existing persons to bodily integrity or freedom from physical violation. ${ }^{28}$

Now consider autonomy; we do clearly have autonomous preferences about what happens to our bodies after death, in so far as these are not complied with, our autonomous wishes have been frustrated, but whether it follows that our autonomy has been violated is another matter. I wish that certain things had not happened to me whilst I was a child. At the time I was not autonomous and had formed no views about them. Did those things frustrate my autonomy because I now wish that they had not been done? Equally with things I now wish will not happen after I lose my autonomy. In neither case does it follow from the fact that someone has autonomous wishes about something that happens when they are not autonomous either in the past or the future, that those things violate their autonomy although they are, of course contrary, to their wishes as held at a particular point in time.

\section{S $1(1)$.}

24. Although this is, I must confess, a rankly partisan reading!

25. Harris, $\mathrm{n} 21$ above, pp 100-101.

26. Of course, it might be argued that taxes serve the interests of all because of the uses to which they are put.

27. There is, I believe, here a lesson to be learned for the case of cadaver organ donation, which I have raised in The Value of Life (London: Routledge and Kegan Paul 1985) pp 219-223.

28. On this point see my 'Ethical genetic research' in (1999) 40 Jurimetrics: The Journal of Law, Science, and Policy 1 at 77. 
This raises an interesting question about why we should respect the advanced directives of individuals who have ceased to be persons. Respecting advanced directives can, I have suggested, have nothing to do with the respect due to autonomy, although most commentators have assumed that it does. ${ }^{29}$ Where individuals who were once autonomous have permanently lost autonomy, it is the responsibility of those who care for them, or who have care of them, to act in their best interests. Knowing what the subject would have wanted is a powerful 'steer' as to what their interests are and hence as to how to act in their best interests. However, some individuals may not have any interests that can be protected. Suppose Tony Bland, the patient left in Permanent Vegetative State (PVS) following the Hillsborough disaster, had left an advanced directive to the effect that he wanted to be kept alive at all costs; would the House of Lords have done wrong to have given permission for the withholding of life-sustaining measures? In English law it is not permissible to kill even those who want to die, and statements of a disinclination to have life shortened do not add to the legal duties we have to preserve life. Equally, while patients may refuse treatment in virtue of their common law entitlement to be protected from unlawful assaults, they may not direct doctors or others to perform any particular treatments (although they may, of course, request them). Lord Mustill in the Bland case noted that: 'The distressing point, which must not be shirked, is that the proposed conduct is not in the best interests of Anthony Bland for he has no best interests of any kind. ${ }^{30}$ While Lord Mustill is perhaps slightly overstating the case, his main point is surely powerful, and that is because of another feature of morality that we need to reflect upon.

\section{Person-affecting restrictions on moral duties}

It is tempting to think of those sorts of interests we have termed 'critical' or 'persisting' as contrasted with so-called 'experiential' interests - interests that we are aware of, and are aware of being either served or not served by what happens. Ronald Dworkin highlights this particular contrast, defining experiential interests as things we have an interest in because we like the experience of doing them. Critical interests, on the other hand, are those 'interests that it does make ... life genuinely better to satisfy'. ${ }^{31}$ Most of our critical interests concern interests we have while alive, but some, as we have noted, survive our deaths. Things that happen after our death can be critical interests of ours just because whether they happen or not may contribute to whether our lives have gone well as a whole. To persevere with the example already used, if my children are provided for after my death, this will make my life more successful overall than if this were not the case; that is why what happens to them is one of my critical interests, whether or not I am there to experience their fate one way or the other. However, there is another distinction that has some importance, and that is whether or not particular interests are 'person-affecting' in the sense that their satisfaction or frustration

29. A related argument in the context of personal identity has been employed by Allen Buchanan: see his 'Advance Directives and the Personal Identity Problem' in I Harris (ed) Bioethics (Oxford: Oxford University Press, 2001) pp 131-157; and also Dworkin (1993), n 17 above, p $180 \mathrm{ff}$.

30. Airedale NHS Trust $v$ Bland [1993] 1 All ER 821 at 894, HL.

31. Dworkin (1993), n 17 above, p $201 \mathrm{ff}$. 
would be good or bad for the person whose interests they are. It is widely accepted in contemporary ethics that 'the part of morality concerned with human well-being should be explained entirely in terms of what would be good or bad for those people whom our acts affect'. ${ }^{32}$ So although what happens to my children, or my body, after my death can involve my critical interests in the sense that it contributes both to the success or failure of my life as a whole and to whether or not it has achieved the meaning with which I had hoped to endow it, such things are not person-affecting; they are not good or bad for me, they do not affect my well-being because 'I' no longer exist. I am simply not there to be affected one way or the other. In short, though in a sense my interests persist, ' $I$ ' do not.

Some, but not all, critical interests will be person-affecting - all experiential interests will, but person-affecting is what counts when we are principally concerned with human well-being, or with personal rights or interests. Posthumous interests are never person-affecting, nor are posthumous frustrations of autonomous choices.

We must, I believe, think of the preferences of subjects about what happens to them after death as not 'self-regarding' preferences, but 'other-regarding' preferences. That is, preferences the value of which must necessarily be balanced against the interests of others and hence cannot have the status of rights - interests that can trump those of others. The self, the subject of the preferences, no longer exists. Ronald Dworkin called such preferences 'external' to distinguish them from 'personal' preferences. ${ }^{33}$ Dworkin suggests that external preferences should count for nothing when set against personal preferences, that only such an approach is compatible with the equal consideration of preferences because, on the assumption that each person is equal (before morality and before the law each counts for one and none for more than one), then only person affecting preferences reflect this conception of equality which is at the basis of our entitlement to have our preferences respected at all. ${ }^{34}$

I attempted to articulate more precisely why persisting interests were of necessity less significant than person-affecting interests some time ago in my Wonderwoman and Superman. ${ }^{35}$

'It is I admit, hard work imagining why one should separate harming someone's interests and harming that someone. But the point of doing so is perhaps this: if we damage the environment irreparably today, this will harm the interests of future generations but it will not harm individuals as yet undifferentiated until they come into being. It harms their interests now and them only when they exist. Similarly the interests of actual people persist after their deaths. When they are alive you can harm (or benefit of course) both the individual and her interests. Once she is dead only her interests remain to be harmed.

32. Derek Parfit, following Jan Narveson, defines the person affecting restriction thus: 'This part of morality, the part concerned with human well-being, should be explained entirely in terms of what would be good or bad for those people whom our acts affect'. See D Parfit Reasons and Persons (Oxford: Clarendon Press, 1984) p 394.

33. See Dworkin (1977), n 17 above, p 234ff.

34. Dworkin's interests in his discussion of this distinction are rather far from ours, and a full discussion would take us too deeply into the theory of equality.

35. Harris, n 21 above, ch 5, pp 100-101. 
This is why the damage to the persisting interests of the dead must be set against the damage to the persisting interests of the living, damage which, in the case of the living, also affects the persons whose interests they are. This double damage will for all practical purposes always give the edge to the interests of the living. ${ }^{36}$

An important conclusion emerges from this discussion. It is that the primacy that has hitherto been very widely accorded to both advance directives of the subject and to the wishes of parents and other relatives of the deceased with respect to posthumous organ and tissue retrieval or retention lacks the justification that has usually been assumed to underpin its central role. That is not to say, of course, that consent here has no justification, but it does show that an altogether different justification is required.

Since the dead subject has ceased to be the subject of person affecting morality, since he or she has neither autonomy rights nor interests to protect, and only some rather attenuated persisting or critical interests, if any, his or her wishes do not have the primacy that rights and person-affecting interests can claim in moral argument. They cannot function, in Dworkin's famous terminology, as 'trumps' in moral and legal argument. ${ }^{37}$ Equally, the wishes of parents or next of kin lack their normal central role. As we have noted, next of kin or 'guardians' are called upon to make decisions for the incompetent only on the assumption that these represent safeguards of best interests or sometimes (I believe erroneously), ${ }^{38}$ as interpretations of the wishes of the incompetent individual. Here again the wishes of next of kin, guardians or other relatives as to what happens to their deceased relation cannot have the primacy that they have traditionally been accorded, in that they represent neither the expression of the rights nor the person-affecting interests of the deceased. They cannot function as 'trumps' in moral argument.

\section{Person-affecting posthumous interests}

We will shortly turn to the question of the moral status of such preferences. Before doing so we should note that there is a sense in which what happens to my body after death is person-affecting; it is just that it is not me who is the affected person. They are person-affecting in the sense that they affect the persons who will benefit from the research and, indeed, the persons who are distressed by the tissue being collected retained or used.

Having expressed scepticism as to the existence of most posthumous rights or interests, we must now turn to the issue of whose rights or interests may be relevant to the question of posthumous retention or use of tissue and organs. And here the issue of consent may now be seen as highly problematic because,

36. While the life of a person then is affected by frustration of interests, the dead are not affected 'in person' by this. Note that it is not a question of experiential versus critical interests, but person affecting versus persisting interests. Person affecting considerations affect living persons whether or not they experience them in the sense of being aware of them. I am affected in person, for example, by malicious gossip; it is person-affecting even if I remain unaware of it.

37. Dworkin (1977), n 17 above.

38. See, for example, my 'The Welfare of the Child' in (2000) 8(1) Health Care Analysis 1-8; and Harris, $n 5$ above. 
as we have noted, the usual basis of respecting the consent of the subject is absent and the consents of others play a role very far removed from the usual one in which consents are requested and given for medical procedures.

\section{Particular consents}

Whose consent is relevant to the retention of tissue or organs from a deceased individual? If we ask who has possible claims to give or withhold consent to the donation or retention of organs, there is:

- the subject;

- relatives or friends;

- the state;

- science generally conceived;

- the hospital; and

- the person lawfully in charge of the body.

It is well established and almost universally agreed now in medical ethics that the subject him or herself is entitled to give or withhold consent to all medical or scientific procedures, and that such procedures cannot, except in extremis, proceed without consent, and we have already noted the basis for the primacy of consent in this context. Where the individual is not competent to give consent, procedures must only be carried out in the best interests of the subject, and consent is sometimes given by parents or guardians, but only on the presumption that they are the most obvious and reliable protectors of the best interests of the subject. They do not have the right to give consent merely because they stand in a particular relationship to the subject, but because the fact that they stand in that relationship creates a presumption that they are appropriate guardians of the best interests of the subject. Where that presumption is defeated, they have no further standing. Here, law and ethics are, I believe, at one. This holds true for all procedures on living, that is existing, beings, persons properly so called. However, once a human individual has died, it is arguable that they have no further moral rights or interests in that they can no longer be harmed or benefited. We have already noted Lord Mustill's firm statement on this matter and also the fact that while, Mustill notwithstanding, it is possible as we have already noticed, to attribute some persisting interests to the dead, these are necessarily somewhat attenuated or weakened interests because they are not person-affecting in any sense with respect to the subject of those interests.

If it could be argued that the interests of a deceased, whether a child or an adult, are harmed by the donation or retention of tissue or organs, then an interest might arise. Absent such an argument, there seems to be no legitimate interest that could be asserted by friends or relatives. Can we find such an interest?

If the organs or tissue were to be used for some immoral purpose, or if their removal or retention constituted some immoral act, for example, gross indecency, or if the process by which they were removed was immoral or indecent in some way, the rights or interests not only of friends or relatives but, indeed, of any citizen might be engaged. But if they are retained for important and realistic scientific purposes or as part of the human tissue archive (see below), the nature of any legitimate ethical role for friends or relatives must be sought elsewhere. 
Secondly, if the relatives or friends are themselves adversely affected by the retention or use of the tissue, then their legitimate interests might again be engaged. For example, all tissue contains DNA from which the complete genome of the tissue provider can be obtained. The information therein contained is also information about family members, and these family members might have legitimate concerns about their own genetic privacy and the use to which such genetic information might be put. This point could be very important as it is becoming widely accepted that where genetic information on individuals is stored, the information should be suitably anonymised and securely held.

They also might have religious or culturally based beliefs about the disposal of the dead, which might be engaged. Finally, they might simply want very much that all the remains of their relative buried with the body, perhaps because it seems to them simply fitting or appropriate. In this case their powerful feelings deserve respect, but so might the powerful feelings of others who want the organs of the dead to be available for science or for life-saving or other therapeutic purposes because this forms part of their deeply held beliefs and values. If we recall the Chief Medical Officer's statement of principle: 'recognising that a family member may need time to consider whether to agree to a post mortem examination and to consider donation of tissue and organs and will not wish to feel under pressure to agree in the moments after death', ${ }^{39}$ we can see that recognising these needs cannot have the priority assumed for them, these needs must, of needs, compete with the similar needs of other families, needs not to be needlessly bereaved for want of donor organs for their relatives for example.

Ultimately, this conflict of interests or of values will be resolved by considerations of which interests or values carry most moral weight, for example, whether the interests served by one set of values are more significant or vital that those of the other. This might happen if one set of values protected an interest in life itself (actually involved saving a life), whereas the counterpoised interest protected some less significant or less urgent value, like a sense of what is appropriate or 'fitting'. Or, the resolution of such differences might turn on a fairly full description of what society would be like if one set of values rather than the other prevailed. For example, if the bereaved could not bury the dead in their own way, they might choose to reject the obligation to do so at all and the burden and expense of this might fall on society.

Suppose we grant that the removal of organs and tissue serves some beneficial altruistic or important purpose? Suppose, for example, that organs are removed posthumously for transplantation and that tissue is removed for storage and investigation for public health reasons, or in the pursuit of therapeutic research. Grant that these uses are altruistic and beneficial to other individuals (those whose lives may be saved by organ donation or those whose diseases may find cures through scientific research) and two things become clear. The first is that it could not be in the deceased's interests to frustrate the course of science or to make more probable the deaths of other people. Thus, if any presumptions are to be made about what the deceased would have wished, it is surely more reasonable to suppose that if the purposes for which the tissue or organs are retained or used are beneficial and altruistic, that the deceased, if they wished anything, would have wished to act beneficially and altruistically towards others. So if any presumption

39. Retained Organs Commission, $\mathbf{n} 7$ above, $\mathrm{p} 7$, para 16 . 
is made in the absence of an advanced directive or a clear autonomous expression of will, it should not be that the deceased would have wished to frustrate altruistic or beneficial purposes; it should rather be a presumption in favour of their good character that they would have wished to promote such purposes.

This 'constraint' on what might be presumed to have been the wishes of the deceased in the absence of evidence to the contrary should surely operate on presumptions made by relatives and friends as well as on those that might be made by public bodies or the courts.

\section{The human tissue archive}

It is now widely recognised that biobanks are of immense importance in diagnosis, prevention, treatment and care within a health-care system and perhaps, above all, for research in medicine and, more particularly, in genetics.

We have already noted the Redfern Report's emphasis: '[T]issue and organs which have been archived are an invaluable asset for medical research. ${ }^{40}$ In an important report submitted to the National Bioethics Advisory Commission (NBAC) of the US, Dr David Korn ${ }^{41}$ has meticulously documented the ways in which archive samples have contributed massively to medical advance and has pointed out their importance for future genetic research. The report of the Danish Council of Ethics into Health Science Information Banks - Biobanks, also stresses their importance. ${ }^{42}$

These reports and other recent research demonstrate the overwhelming importance of the human tissue archive. It is vital not only in the national interest, but also in international interest that human tissue continues to be archived and that research and therapeutic access to archive tissue is protected. Indeed, new and additional banks continue to be proposed. Biobank UK has now been launched, and plans to recruit initially 500,000 donors of genetic information. ${ }^{43}$

Korn's report emphasises that:

'The history of medical progress has been created over countless centuries from the careful observation and study of normal and diseased individuals. Medical historians place the birth of the discipline of pathology in Renaissance Italy, when physicians first began systematically to perform autopsies on patients they had treated and to incorporate the results into their final summary of the individual case record ... From that origin to the present time the discipline of pathology has contributed essentially all of the vocabulary and much of the intellectual foundation of contemporary medicine. The development of this knowledge base has come largely from the systematic clinico-pathologic study of human tissue samples removed during the course of medical care, combined synergistically with experimentation in suitable animal models, employing over time the latest in contemporary scientific technologies. ${ }^{34}$

40. Redfern Report, $\mathrm{n} 3$ above, $\mathrm{p} 445$.

41. Korn, $n 2$ above.

42. Health Science Information Banks - Biobanks Report of the Danish Council of Ethics, Copenhagen (1996).

43. See Protocol for the UK Biobank, $\mathrm{n} 2$ above.

44. Korn, $\mathrm{n} 2$ above, pp 1-2. 
And concludes that:

'Although not specifically collected for research purposes, these specimens have served as a rich and irreplaceable source of materials for clinicopathological investigations that have provided over the past more than 100 years most of the vocabulary and much of the intellectual foundation of modern medicine. ${ }^{45}$

And insists:

'Inadequate attention has been given to scientific opportunity, the individual, family and societal burdens of major, chronic diseases, and the rich prospects of public benefit that are now in sight as a result of 50 years of generous public investment in biomedical research ... To achieve that promise, public policy must continue to encourage the accumulation of the human tissue archive and facilitate its accessibility for medical research. ${ }^{46}$

While the public policy and public health imperatives seem to be clear, the ethical problems in acting on those imperatives are many and various. As Korn himself notes, the samples were usually 'removed for medical reasons, under sparing consent language $\ldots$ and were not specifically collected for research purposes'. Sometimes samples were taken but no consent to research or investigation was given. In other cases, samples were acquired in ethically dubious or downright immoral circumstances.

For example, one of the major Danish hospitals for the mentally ill collected the brains from patients who died at the hospital during the period from about 1920 to the early 1950s. This was done without the consent of the patients or their relatives. This was legal and, indeed, was customary practice at the time, but would obviously be illegal and impossible today.

The resulting brain repository contains a little over 7,000 brains, together with the matching patient records containing information about symptoms, diagnosis and disease development. This brain repository is now a very valuable resource for research into possible structural changes in the brain in patients with psychiatric disease. The brains were collected before the introduction of neuroleptic drugs (and most other kinds of pharmacological treatment in these patients), and it is thus possible to distinguish between changes related to the disease in itself, and changes related to the treatment. The brains have, for instance, been used in studies about the number and density of neurones in various parts of the brain in untreated schizophrenics. Studies which have shown that the lack of neurones previously identified in brains recently obtained from deceased treated schizophrenics is not a result of neuroleptic treatment, but directly related to the disease.

Some Danish commentators have suggested that because the brains were obtained without consent, their use in research is inherently illicit. Some have even suggested that all 7,000 brains should be buried in a common grave and a monument erected on the grave. ${ }^{47}$

The burden of the Korn report, which is substantial and detailed, is that the techniques and therapies available through modern medicine from which we

45. Korn, $\mathrm{n} 2$ above, $\mathrm{p} 41$.

46. Korn, $\mathrm{n} 2$ above, $\mathrm{p} 42$ (emphasis in original).

47. Personal communication from Søren Holm. 
all benefit have been provided in very large part as a result of the study of retained tissue and organs, and that we all, therefore, have an immense interest not only in the past use of such retained tissue and organs, but in its continuing collection and availability for research. This is not, of course, to say that such organs and tissues should be retained without consent nor, and still less, in violation of the clearly expressed wishes of the individuals concerned, although, as we have noted, the strength and justification of these constraints is rather weaker than has so far been acknowledged. We all have an interest in the collection and retention of such tissue and organs and that in the absence of specific refusals from competent individuals, if any presumptions are made about their wishes, it should be that they would wish to contribute to the science base from which they have benefited and that third parties, even if those third parties are friends and close relatives, have no moral basis on which to claim an entitlement to substitute their own preferences and consents for those of their deceased friends or relatives. If we look at just one final example from the Korn Report we can see the unparalleled importance or archive tissue. I quote at some length because debates about retained organs and tissue have thus far been remarkably short on the detailed case for the continued availability of retained organs and tissue.

\section{The case of atherosclerotic cardiovascular disease (ASCVD)}

'The leading cause of death in the United States continues to be atherosclerotic cardiovascular disease (ASCVD). It has been known for many decades that the major, medically devastating consequences of ASCVD tend to become manifest in middle and advanced age and as late as the middle of the 20th century, it was generally believed that the underlying atherosclerotic disease processes were themselves processes of middle and old age. That belief, naturally shaped the entire medical strategy for dealing with ASCVD. But during the past forty or more years there has been a remarkable shift in the approach to these diseases, based on new information that led to the recognition that a very large fraction of the morbidity, and probably the mortality, of ASCVD is preventable. There has been a remarkable change in the nation's dietary and recreational habits such that although heart disease continues as this country's number one cause of death, people live longer and healthier lives because of new knowledge about the relationship of diet, smoking and exercise to cardiovascular health. In addition, of course, powerful new surgical and medical therapies have enabled many of those in whom ASCVD has become manifest to continue to lead active, productive lives.

The cornerstone of the science that led to this profound change in conception of ASCVD and the formulation of new preventive strategies for mitigating its impact on the population was laid in 1953. Three military pathologists who were performing autopsies on Korean war casualties were charged with documenting chest wounds from artillery. In the process they noticed and systematically recorded information on the types and extent of atherosclerotic changes in the coronary arteries of these young, otherwise healthy and largely male adults, a population not at that time considered to be at risk from ASCVD. The reports based on those observations revolutionized thinking about the onset and progression of coronary heart disease, and subsequently, other manifestations of ASCVD as well. 
The reports were based on 300 autopsies of individuals averaging 22.1 years of age. The casualties were primarily U.S. soldiers, but some Korean prisoners of war and Japanese civilians were also studied for comparative purposes. Evidence of coronary arteriosclerosis was found in $77.3 \%$ of the hearts from the U.S. soldiers, while in the Korean soldiers and Japanese civilians, although some early atherosclerotic changes were observed, the extent of the changes were strikingly less than in the American casualties. Moreover, in the eight soldiers whose coronary arteries demonstrated occlusion ranging from $95 \%$ to total, only one was older than 22 years of age. An editorial published in Journal of American Medical Association some 35 years later reflected on how these carefully documented and totally unexpected autopsy findings had changed our thinking and behaviour concerning atherosclerosis. ${ }^{48}$

The Korn Report shows, through the very many examples of a similar sort that it cites, the indispensability of retained human organs and tissue in scientific research and therapeutic advance. The point of citing the importance of the Human Tissue Archive is not to establish that there is a moral duty to contribute to it (although there may well be!), but rather to point out that refusal to contribute to the human tissue archive is a deeply selfish and immoral act, and that in the absence of clearly expressed refusals by the individuals whose tissue and organs are in question, two important consequences follow. The first is that their friends and relatives or others have no moral reasons to assume that refusal of consent to archive tissues is consistent with either public or personal morality or is required by any of society's moral purposes. Secondly, that if any presumptions are made about what the deceased would have wanted, it should be that he or she would have wanted to contribute to, or at least not frustrate, the maintenance of a resource that has saved and will continue to save so many lives.

\section{The right to possess and dispose of the body}

Relatives of people whose organs have been retained after death often claim that they have both an obligation and a right to possess and dispose of the remains. What might be the ethical basis for this right and duty? If there is an ethical basis, it seems to relate to the need for bodies to be disposed of in a way that serves three important goals. They are to ensure there is no public or personal health risk, to ensure that conceptions of public decency are not outraged and to satisfy the legitimate interest of the bereaved in all the processes connected with death - mourning, funeral rites and so forth. Arguably, these latter interests of the bereaved are subordinate here to the first two justifications for the imposition of a legal duty to dispose of the body. That is, in terms of the ethical basis for the legal duty to dispose of the body, the public health and public decency concerns take priority over the entitlement to the processes associated with bereavement and with the dignity of the dead. These latter interests are of course more central in the light of the Human Rights Act 1998 which we discuss in the next section. This would be supported, I imagine in terms of English law, by the powers of the courts and/or the coroner to order post-mortem examinations and the retention of organs or tissue, whether the family wish it or not.

48. Korn, $\mathrm{n} 2$ above, pp 12-13. 
In the absence of any powerful public health or public decency countervailing considerations, the bereaved's third basis for possession of the body may be sound. These interests are no more powerful from an ethical perspective than the interests of others in the beneficial use of tissue and organs. However, the question of whether or not possession of the body means either in law or in ordinary language possession of every part of the body that was within the physical confines of the body at the moment of death seems more doubtful. Just as it is inevitable that there should be some loss of tissue between the time of the death and the time of the funeral, whether or not there has been a post-mortem examination, so it is also probable that there will be some gain of 'foreign matter'. Flies may lay eggs and maggots may form in relatively short periods after death, depending on how the body has been stored post mortem, and if an autopsy has taken place, the body cavity will, in addition to organs replaced after examination, also contain the plastic bag or bags into which the organs are placed, 'stuffing' (usually in the form of shredded paper) for the main orifices of the body, and also the sutures etc used to stitch the body together. That said, if there is a right to all the human remains or a duty to dispose of all that remains of the deceased, then this would encompass all remains that can reasonably be traced and collected. But note that such an interpretation of the right or duty puts all the weight on this being in accord with the interests of the bereaved it could not be required by public health considerations, nor yet by conceptions of public decency.

\section{Rights to respect for family life and freedom of thought and conscience}

A second source of support for the priority of the claims of relatives to determine the fate of the bodies of their kin comes from the European Convention on Human Rights and its embodiment in UK law in the form of the Human Rights Act $1998 .{ }^{49}$ Here again, these rights are highly problematic when specific content is debated. Family life would certainly include as an important element the process of bereavement and funeral rites. Whether non-interference in these includes the non-retention of tissue and organs from the deceased is highly problematic given the 'facts of life' which mean that the idea of a 'complete' corpse (without subtractions or additions) is, as we have seen, intellectually incoherent. Equally, freedom of thought, conscience and religion is likely to include beliefs about the disposal of the dead. But such beliefs are not absolute rights in moral terms which trump other beliefs and values. They are moral claims, which compete against other moral claims. To take two examples far from our present concerns: many religions and cultures have beliefs about the ways in which animals should be slaughtered for food. Such beliefs, where they exist, do not confer absolute entitlements to slaughter animals in these ways, but must be measured against moral conceptions of animal welfare and food hygiene. Or take the case of male or female circumcision for cultural or religious reasons; again, the respect due to cultural or religious beliefs or practices does not put such practices beyond the scope of moral evaluation by those outside the culture or religion.

49. Support for such claims in the Human Rights Act 1998 are principally found in ss 6(1), 6(3)(a) and arts 8 and 9 of Sch 1 to the Act. 


\section{Respect and reverence}

A quite absurd, if understandable, preoccupation with reverence and respect for bodily tissue has come to dominate discussions of retained tissue and organs in the wake of the Alder Hey revelations. We do not normally feel this reverence for our bodily remains, tissue and organs while alive - why suddenly this morbid post mortem preoccupation? Consider that toilet-paper, soiled bandages, plasters and 'band-aids', not to mention hospital 'sharps' (needles and blades etc) all have human blood and tissue and hence the whole genome attached and are usually discarded and disposed of without any clamour for respect and reverence. In post-mortem examinations, the contents of the bowel are usually unceremoniously washed away to allow inspection of the intestinal lining..$^{50}$ It has not so far been suggested that these should be collected and interred with the body or, if this has not happened, should be traced and returned to the family for dignified disposal and yet they contain many more cells and tissue fragments that the 'blocks' and 'slides' that have been the subject of serious, and, one cannot help but observe, seriously misplaced, consideration. The Retained Organs Commission consultation document also refers to whole bodies including the bodies of 'pre-term and still-born babies', st but not all disposal of whole bodies engages the same degree of reverence or concern. The sanitary towels of sexually active women will often contain embryos, whole 'bodies' in some sense, but their disposal is not usually a particularly reverential process, nor do Catholics, for example, insist on precautionary menstrual baptisms. ${ }^{52}$ Such inadvertence is not simply a matter of lack of attention. We probably could not insist that 'attention must be paid' because it is probably not psychologically possible to think of body parts, or even whole bodies, that we discard in these circumstances as requiring particular respect or reverence. Now, it might be said that there is a difference between our attitudes to our own bodies while we are alive and our feelings about respect for the bodily remains of the dead. But, if there is this difference, a problem arises. Since all living persons will die, their body parts discarded while alive are none the less part of their remains once they die, and in so far as burial intact or respectful disposal is an issue, there is clear inconsistency here.

Consider the following example. During an operation, to remove an inflamed appendix some cancerous material is discovered and the diseased tissue is also removed, blood and bodily fluids are lost and bandages, swabs and disposable instruments covered in blood and tissue are left over. Normally, these would be incinerated for safety reasons, but some tissue samples might be retained for further examination. The patient unfortunately dies in the recovery room. Do we suddenly feel differently about the tissue and organs removed and 'retained' because we are now dealing with post-mortem retention?

That there is no great unease caused by such comprehensive inconsistency shows, I think, that we have only very recently developed a morbid interest in bodily remains, which has been distorted by over-concentration on a peculiar, but highly unrepresentative, case. It is difficult to draw clear

50. Søren Holm pointed this out to me.

51. Retained Organs Commission, $\mathrm{n} 7$ above, $\mathrm{p} 9$.

52. I am here indebted to Ann McLaren for helpful insights. 
conclusions, but the inconsistency of our attitudes betrays at the very least ambivalence about body parts and bodily remains. We should be very cautious about drawing general conclusions, and still more cautious about formulating principles and guidelines, which should govern our attitudes to the collection, retention and use of body parts and bodily remains on the basis of one very particular case.

\section{Rationality}

The human body cannot for long remain intact after death. It is perishable and will, as has been chronicled in art and literature since time immemorial, inevitably decay, disintegrate and turn to dust ... or worse! We have already noted that following post mortem there will be inevitable loss of tissue in the form of blood and bowel contents, at the very least, and inevitable gain of other 'foreign' matter. Everyone knows that the idea that bodies can remain intact (whatever 'intact' might mean) is an illusion. It is not a dark secret, like knowledge of exactly what happens at post-mortem examinations. Shakespeare, as ever, tells it like it is. In this conversation between Hamlet and Horatio the inevitable fate of the dead is made both vivid and comic:

'Hamlet. Prithee Horatio, tell me one thing.

Horatio. What's that my Lord?

Hamlet. Dost thou think Alexander looked o' this fashion I' the earth?

Horatio. E'en so,

Hamlet. To what base uses may we return Horatio! Why may not imagination trace the noble dust of Alexander, till 'a find it stopping a bung hole?

Horatio. 'Twere to consider too curiously, to consider so.

Hamlet. No, faith. Not a jot, but to follow him thither with modesty enough, and likelihood to lead it; as thus-Alexander died, Alexander was buried, Alexander returneth into dust, the dust is earth, of earth we make loam, and why of that loam, whereto he was converted, might they not stop a beer-barrel? Imperious Caesar, dead and turned to clay,

Might stop a hole to keep the wind away.

$\mathrm{O}$, that that earth, which kept the world in awe,

Should patch a wall to expel the winter's flaw!'53

No dead body remains intact; the worms (a certain convocation of politic worms - if one is lucky!) or the fire and eventually dust claim it. It is disintegrated, dispersed and may end as the bung in a beer barrel or the mortar in a wall. The alternatives are not burial intact or disintegration. There is simply no alternative which does not involve disintegration. As Hamlet again makes clear talking of this process:

'...your worm is your only emperor for diet, we fat all creatures else to fat us, and we fat ourselves for maggots. Your fat king and your lean beggar is but variable ser vice, two dishes to one table-that's the end. ${ }^{54}$

53. W Shakespeare Hamlet Act V, Scene I.

54. Shakespeare, n 53 above, Act IV, Scene III. 
Given that there is no alternative, the complaint of those who object to actions that violate the physical integrity of the corpse is scarcely rational. Illusions are fine, but whether the state and the courts should give judicial or official support to these illusions is more doubtful, particularly when so to do might deprive others of the possibility of life-saving therapies. The families involved in the misdeeds at Alder Hey deserve our sympathy and respect, not least because they have been deceived and unnecessarily distressed. But they are not the only bereaved families in the world. Almost all families have experienced bereavement, and all will at some point suffer irreparable loss. We should not let the agenda on such an important issue as organ retention and use be set by those forced to view it through the distorting lens of grief, particularly when one result may be that other families may well have to suffer grief prematurely as a result.

\section{CONCLUSIONS}

Consent or 'authorization' 55 is always preferable to conscription, even where neither consent nor authorisation are strictly required by either ethics or law. However, it will be obvious that the burden of the argument of this paper is that, failing consent or authorisation, conscription of the use of post mortem organs and tissue where these are required for important moral purposes is morally and (probably) legally justifiable, and should be seriously considered. ${ }^{56}$

Specifically, the following conclusions emerge:

- In the case of posthumous organ retention, the consent of the deceased, whether expressed by advanced directive or more informally, does not perform the normal role of consent in protecting autonomy, bodily integrity or well-being from unlawful or unethical assaults. Respect for consent here is more like extending a courtesy than respecting a right.

- The consent of parents, other relatives or friends to post-mortem retention and use of tissue and organs does not perform the normal function of third-party consent in ensuring that any interventions are in the best interests of an incompetent subject. This means consent of parents or other relatives to organ retention or use is not required where more important personaffecting interests of others conflict. Again, if consent is sought and acted upon, this is more like extending a courtesy than respecting a right.

- Dead human beings have no autonomy interests to protect.

- Dead human beings have no rights which require protection.

- Human beings can have some so-called 'persisting' or 'critical' or 'enduring' interests which survive death, but since none of these affect the well-being of the subject of the interests or are 'person affecting' with respect to that subject, they are necessarily less important than comparably weighty interests that are 'person affecting' with respect to other existing individuals.

- The human tissue archive is an important research and therapeutic resource, which we all have a strong interest in protecting and supporting.

55. Scottish Executive Final Report of the Independent Review on the Retention of Organs at Post Mortem (2001). The Scottish concern about the language of consent is not shared by the Northern Ireland Inquiry: see the Report of the Human Organ Inquiry (2002).

56. See Harris, n 27 above, ch 6 and p 222 . 
- The right to possess and dispose of a dead body serves a number of public interests, which have to be balanced against the interest of the bereaved.

- Rights to respect for family life and of freedom of thought, conscience and religion protected by the Human Rights Act 1998 affect and benefit all people. The rights of the bereaved under this Act have to be balanced against those of others who might be affected.

- People generally are ambivalent about bodily remains, exhibiting different attitudes to their own and others detached body parts at different times or on different occasions. There is often a marked difference in attitudes to body parts shed while the subject is alive and those lost post mortem. We may include it to be unsafe to generalise about the appropriate rules governing retained body parts if such rules are to reflect public attitudes or beliefs.

- While some people talk about the importance to themselves and those they care about of posthumous bodily integrity, this is an illusion and the fact that everyone knows this hope to be illusory is some evidence as to the irrationality of the desire. 